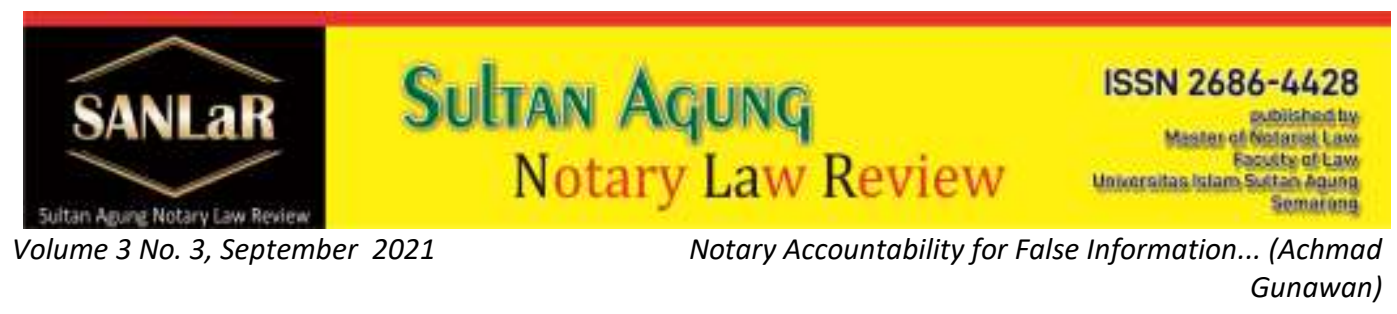

\title{
Notary Accountability for False Information by Appellant in Establishment Deed of Limited Liability Company
}

\author{
Achmad Gunawan*) \\ ${ }^{*}$ Faculty of Law, Universitas Islam Sultan Agung (UNISSULA) Semarang, E-mail: \\ achmadgun2021@gmail.com
}

\begin{abstract}
The purpose of this research is to analyze and find out: 1). Procedure for Making a Deed of Registration of a Limited Liability Company. 2). The form of the Notary's liability for the deed of establishment of a Limited Liability Company made based on false information. The approach method in this research is normative juridical. The data used are primary and secondary data obtained through interviews and literature study, data analysis was carried out by analytical descriptive. The results of the research concluded: 1). The procedure for making the registration deed of a Limited Liability Company (PT) is that it must meet the requirements in an establishment of a PT other than what has been regulated in Article 7 paragraph (1) of the Company Law, which must be based on an agreement made by 2 (two) or more persons, the form of the Deed of Establishment of a PT must also be in the form of a Notary Deed drawn up in the Indonesian language, in other words, in this case the Notary has the role of making a Deed of Establishment of a PT, which functions as probationis causa and solemnitas causa. 1) The notary is only formally responsible for the documents shown to him, in which the notary has no obligation to materially prove the truth of the documents shown to him. However, the notary must conduct an examination of all documents submitted to him which then also asks the appearer for information to be synchronized with the information contained in the document, in which case there are irregularities related to the documents and information submitted to him, the notary may refuse to continue the stages of making the deed. . Notaries can only be held accountable if the Notary is proven to have violated the provisions of Articles 84 and 85 of the UUJN and the notary code of ethics, which can be held criminally, civilly and administratively responsible.
\end{abstract}

Keywords: Accountability; False; Information; Appellant; Establishment; PT. 


\section{Introduction}

An authentic deed made by a notary is a means of proof to state the existence of a legal act carried out by the appearer. As evidence, an authentic deed is said to have perfect evidentiary power because it has three powers of proof, namely the power of outward proof, the power of formal proof, and the power of formal proof.proofmaterial. The power of outward proof (uitwendige bewijskracht) is the ability possessed by an authentic deed to prove its validity as an authentic deed that was born in accordance with the rule of law regarding the requirements of an authentic deed. The power of formal evidence (formele bewijskracht), namely the ability to provide certainty that an event and fact mentioned in the deed was indeed carried out, related to the date or time of manufacture, identity of the appearers, signatures of the appearers, witnesses, and notaries, place of manufacture deed, as well as information or statements seen, witnessed, heard or delivered by the appearers. The strength of material proof of a deed. ${ }^{1}$

In practice, it is often found, if there is a notary deed in dispute by the appearers or other third parties, then the notary is often withdrawn as a party who participates in committing or assisting in committing a criminal act, namely making or providing information. Notary is a legal profession so that the notary profession is a noble profession (nobile officium). The deed made by a notary can be a legal reason for the status of a person's property, rights, and obligations. Mistakes in the deed made by a notary can cause a person's rights to be revoked or someone's obligation to be burdened. Therefore, a notary in carrying out his duties must comply with the various provisions stipulated in the Law on Notary Positions.

The statement or statement of the parties by the Notary is included in the notary deed. So that in civil cases, the authentic deed is evidence that is binding and coercive, meaning that the judge must assume that all legal events stated in the authentic deed are true, unless there is other evidence that can eliminate the power of proof of the deed. ${ }^{2}$ A notarial deed has perfect evidentiary power so that if there is a person or party who judges or declares the deed is not true, then the person or party who judges or declares it is obliged to prove his assessment or statement in accordance with the rule of law. ${ }^{3}$

\footnotetext{
${ }^{1}$ Sjaifurrachman dan Habib Adjie, 2011, Aspek Pertanggungjawaban Notaris Dalam Pembuatan Akta, Mandar Akta, Bandung, p. 116-118.

${ }^{2} \mathrm{Habib}$ Adjie, 2008, Hukum Kenotariatan di Indonesia-Tafsiran Tematik Terhadap UU No. 30 Tahun 2004 Tentang Jabatan Notaris, Bandung, Refika Aditama, p. 46.

${ }^{3}$ Habib Adjie, 2008, Hukum Notariat di Indonesia : Tafsir Tematik Terhadap UU No.30 Tahun 2004 Tentang Jabatan Notaris, Refika Aditama, Bandung, p.14.
} 
If there is a civil lawsuit or criminal complaint from one of the parties, it is possible that the notary will be involved in the problems of the litigants regarding the deed made by the notary. In practice, it is often found, if there is a notarial deed in dispute by the parties or other third parties, the notary is often withdrawn as a party who participates in committing or assisting in committing a criminal act, namely making or providing false information in the notary deed. In this case the notary intentionally or unintentionally the notarytogether-together with the parties/appearers to make a deed with the intent and purpose of benefiting only certain parties or appearers or harming other appearers must be proven in court. ${ }^{4}$

One example of a problem that brought a Notary into the realm of a lawsuit occurred in the establishment of Limited Liability Company X (PT. X) domiciled in South Jakarta. In this case, Mr. A filed a lawsuit to the Surabaya District Court to cancel the Deed of Establishment of PT. X which was made before Notary $Z$ because there was falsification of data in the identity of the founder of PT. X. In the lawsuit filed by Mr. A as the Plaintiff, the person concerned argues that there is a defect in his willestablishmentPT. $X$ because one of the founders of PT. $X$ provided false identity data when making the deed of establishment of PT. X before Notary Z. The False Information was allegedly given by Mrs. B who at the time of manufacture did not inform her that the person concerned had Singaporean citizenship.

In the basis of the lawsuit filed by Mr. A, it was also stated that Notary Z was placed as a Defendant because as a Notary he was deemed to have acted less carefulor inadvertently and carefully entering the identity of Mrs. B as an Indonesian citizen. Therefore, Notary $Z$ is considered to have committed an unlawful act.

\section{Research Methods}

The approach method used in this study is a normative juridical approach. Primary and secondary data sources obtained by interview method and literature review (study document). The data that has been collected both from field research and library research were analyzed using descriptive analysis methods.

\section{Results and Discussion}

\subsection{Procedure for Making Registration Deed of Limited Liability Company (PT)}

Limited Liability Company (hereinafter referred to as PT) is a form of business entity with economic activity that is in great demand at this time, this is due to

${ }^{4}$ Ibid. p.78. 
its limited liability and ease of transfer of share ownership by shareholders by PT is regulated in Act No. 40 of 2007, therefore to establish a PT must be subject to the rules contained therein. In this case the PT is a legal entity whose establishment has been regulated in Article 7 paragraph (1) of the Company Law, it must be based on an agreement made by 2 (two) or more people, where the agreement must still meet the elements of a valid agreement as stipulated in Article 1320 of the Civil Code, namely: ${ }^{5}$

1. Agree on those who bind themselves;

2. The ability to make an engagement;

3. A certain thing;

4. A lawful reason.

Another requirement for the establishment of a Limited Liability Company other than what has been regulated in Article 7 paragraph (1) of the Limited Liability Company Law is that it must be based on an agreement made by 2 (two) or more people. In other words, in this case the Notary has a role to make the Deed of Establishment of a PT, which functions as a probationis causa and solemntasis causa. ${ }^{6}$

In Article 8 paragraphs (1) and (2) of the Company Law, it is stated that the Deed of Establishment of the PT contains the Articles of Association and other information at least: ${ }^{7}$

a. "Full name, place and date of birth, occupation of residence, and nationality of the individual founder, or the name, domicile and complete address as well as the number and date of the Ministerial Decree concerning the legalization of the legal entity from the founder of the Company;

b. Full name, place and date of birth, occupation, place of residence, nationality of the first appointed member of the Board of Directors and Board of Commissioners;

c. The name of the shareholder who subscribed to the shares, details of the number of shares, and the nominal value of the shares that have been issued and paid up."

The Deed of Establishment of a PT which contains the Articles of Association of the PT as stipulated in Article 8 must contain all the provisions stipulated in Article 15 paragraph (1) of the Limited Liability Company Law which contains at least:

\footnotetext{
${ }^{5}$ Code of Civil law

${ }^{6}$ M. Yahya harahap, 2016, Hukum Perseroan Terbatas ed.6, Sinar Grafika, Jakarta,p.169

${ }^{7}$ Act No. 40 of 2007 concerning Limited Liability Companies
} 
a. "Name and domicile of the Company;

b. The purposes and objectives and business activities of the Company;

c. The period of establishment of the Company;

d. The amount of authorized capital. Issued and paid-up capital;

e. Number of shares, classification of shares if any, including number of shares for each classification of shares, rights attached to each share, and nominal value of each share;

f. Name of position and number of members of the Board of Directors and Board of Commissioners;

g. Determination of the place and procedures for holding the GMS;

h. Procedures for the appointment, replacement, dismissal of members of the Board of Directors and the Board of Commissioners;

i. Procedures for the use of profits and distribution of dividends."

A Limited Liability Company can also be interpreted as an association of shareholders created by law and treated as an artificial person by the court, which is a legal entity and is therefore completely separate from the people who founded it by having the capacity for continuous existence and as a legal entity, limited liability company is authorized to receive, hold and transfer assets, sue or be sued and carry out other authorities granted by applicable law. ${ }^{8}$

The formulation of Article 1 point 1 of the Limited Liability Company Law expressly states that a Limited Liability Company is a legal entity. This formulation certainly has the consequence that as a legal entity, a Limited Liability Company has the characteristics and ability to act as a legal entity. ${ }^{9}$

Rochmat Soemitro said that a legal entity is an entity that can have assets, rights and obligations like an individual. Furthermore, Wirjono Prodjodikoro expressed the notion of a legal entity as an entity which besides being an individual human being is also considered to be able to act under the law and which has rights, obligations and legal relations towards other people or other entities. ${ }^{10} \mathrm{~A}$ legal entity is also an independent legal subject that is equalized before the law with private individuals, although it can be the bearer of its own rights and obligations, regardless of the people who founded or are members of the law, it is not one hundred percent the same as private individuals. individuals. For legal entity ownership of certain assets, the main source of assets separated by individuals is specifically intended for use in accordance with the aims and

\footnotetext{
${ }^{8}$ Munir Fuady, 2003, Perseroan Terbatas Paradigma Baru, Citra Aditya Bakti, Bandung, p.2

${ }^{9}$ Gunawan Widjaja, 2002, Seri Hukum Bisnis Tanggung Jawab Direksi atas Kepailitan Perseroan, Raja Grafindo Persada, Jakarta, p. 15

${ }^{10}$ Gunawan Widjaja, 2008, Risiko Hukum sebagai Direksi, Komisaris \& Pemilik PT, Forum Sahabat, Jakarta, p.13
} 
objectives of the legal entity. The purpose and objective of the separation of certain assets for the purposes of a limited liability company. ${ }^{11}$

According to Kuswari Ahmad, ${ }^{12}$ The first step in the procedure for making a legal entity registration deed for a limited liability company is to prepare the name, what the company is, the address where and the structure of the organs. Later, we will see how much authorized capital is, then from $25 \%$ authorized capital, it becomes the set capital, for example IDR 100,000,000.00 (One hundred million rupiah) means IDR 25,000,000.00 (Twenty five million rupiah) authorized capital.

But if you refer to the examples of problems in this case, the examples of problems that brought the Notary into the realm of lawsuits occurred in the establishment of Limited Liability Company X (PT. X) domiciled in South Jakarta. In this case, Mr. A filed a lawsuit to the Surabaya District Court to cancel the Deed of Establishment of PT. X which was made before Notary $Z$ because there was falsification of data in the identity of the founder of PT. X. In the lawsuit filed by Mr. A as the Plaintiff, the person concerned argues that there is a will in the establishment of PT. $X$ because one of the founders of PT. $X$ provided false identity data when making the deed of establishment of PT. X before Notary $Z$. The False Information was allegedly given by Mrs. B who at the time of manufacture did not inform her that the person concerned had Singaporean citizenship.

When making the deed PT. X on 18 August 2018, Mrs. B used an identity in the form of an Indonesian Identity Card, while according to Mr. A, the person concerned has had Singaporean citizenship since 23 March 2017 or more than 1 (one) year prior to the establishment of PT. X. Based on this condition, Mr. A filed a lawsuit to cancel the deed of establishment of PT. $X$ because there is a will in the agreement to establish PT. the X. The defect of will stated that if Mrs. B had not committed the related fraud then the person concerned would not have entered into the agreement. The provisions of Article 1328 of the Civil Code which states: "Fraud is a reason to cancel an agreement, if the fraud used by one of the parties is in such a way, so that it is clear that the other party will not enter into the agreement without some deception. Fraud cannot only be estimated, but must be proven. So on that basis A filed a lawsuit.

In the basis of the lawsuit filed by Mr. A, it was also stated that Notary Z was placed as a Defendant because as a Notary he was deemed to have acted less carefully or not carefully and carefully entered the identity of Mrs. B as an Indonesian citizen. Therefore, Notary $Z$ is considered to have committed an unlawful act. Mrs B has had Singaporean citizenship since 2017, one year before

11 Ibid.

12 Interview with Kuswari Ahmad, SH, M. Kn, Notary/PPAT in Bengkulu City on August 5, 2021 
the establishment of PT X. But when Mrs. B presented her identity, Mrs. B gave her an Indonesian Citizenship ID card, here her position means that Mrs. B has two ID cards, an Indonesian Citizenship Identity Card and a Foreign Citizenship Identity Card. Actually, in this position, where is the notary's fault? How can a notary check citizenship, because the one with more authority is the government agency. We notaries also can not,

\subsection{Form of Notary Liability for the Deed of Establishment of a limited liability company made based on false information}

UUJN authorizes notaries to provide legal counseling in connection with the making of the deed with the aim that the parties can understand the applicable law, so that the law can institutionalize and even animate each of the parties concerned. The goal is not just to provide information or information about the law that needs to be known, but to seek to foster and increase legal awareness of the parties concerned, so that legal compliance and obedience arises, on the basis of the assumption that the law is in accordance with applicable values or which he adheres to. ${ }^{13}$

On the basis of this authority, in carrying out its duties and obligations, notaries are required to provide legal certainty and professional services. In realizing the 2 (two) sides of the work that contain a lot of risks, it is necessary to have sufficient legal knowledge and high accuracy and responsibility. For this reason, in daily practice, notaries are required to always uphold the laws and principles of the state and act in accordance with the meaning of the oath of office and prioritize their service to the interests of the community and the state. There are obligations of good personality and demands to uphold the dignity of the position of a notary, thus in carrying out his position a notary is not justified in doing things and/or actions that are not in accordance with the dignity and honor of a notary position ${ }^{14}$.

The position of a Notary has two essential characteristics and characteristics, impartiality and independence in providing assistance to its clients. It is a credo,

\footnotetext{
${ }^{13}$ Utomo, Hatta Isnaini Wahyu, 2019, Memahami Pelaksanaan Tugas Jabatan Pejabat Pembuat Akta Tanah, Phoenix Publisher, Yogyakarta, p. 29

${ }^{14}$ A Chuasanga, Ong Argo Victoria. (2019). Legal Principles Under Criminal Law in Indonesia Dan Thailand, Jurnal Daulat Hukum, Vol 2, No 1 (2019) http://jurnal.unissula.ac.id/index.php/RH/article/view/4218 and Deen, Thaufiq., Ong Argo Victoria \& Sumain. (2018). Public Notary Services In Malaysia. JURNAL AKTA: Vol. 5, No. 4, 1017-1026. Retrieved from http://jurnal.unissula.ac.id/index.php/akta/article/view/4135
} 
a belief, that these two characteristics are attached to and identical with the behavior of the perpetrators of this position. ${ }^{15}$

According to Habib Adjie, even though a Notary is administratively appointed and dismissed by the government, it does not mean that a Notary is subordinate to the government. Thus, the Notary in carrying out his duties:

a. Is independent (autonomous);

b. Not taking sides (impartial);

c. Does not depend on anyone (independent), which means that in carrying out the duties of his position he cannot be interfered with by the party who appointed him or other parties. ${ }^{16}$

The position of a Notary as an honorable position and has a very important role in society, of course, requires that whoever holds the position has qualified qualities both scientifically and in leadership. Science, especially in the field of law, must be thoroughly understood by Notaries. This is reflected in one of the requirements for the appointment of a Notary as stated in Article 3 letter e of the UUJN is "Graduate of Law Degree and pass the Notary degree level two". ${ }^{17}$

In carrying out his position in a professional manner, it is felt increasingly important because the position of a notary as a public official deals directly with the interests of the community in providing assistance or services. If this is not given properly or professionally, then later there will be parties who are harmed as a result of the law from errors or omissions that have been made by the notary. ${ }^{18}$

The responsibility of a notary in the UUJN is intended as a notary's attachment to legal provisions in carrying out his duties and obligations, in the sense that all notary actions in carrying out their duties must be legally accountable, including with all the consequences to be subject to legal sanctions for violations of norms the underlying law. When the deed made by the Notary in the future has problems or causes harm to one of the parties in the deed, in this case the notary cannot be directly blamed or held accountable, because the notarial deed is a wish and request of the parties, not suggestions or opinion of a notary, but the

\footnotetext{
${ }^{15}$ Budiono, Herlien, 2013, Kumpulan Tulisan Hukum Perdata di Bidang Kenotariatan, Buku Kedua, Citra Aditya Bakti, Bandung, p.281.

${ }^{16}$ Adjie, Habib, 2008, Hukum Notariat di Indonesia : Tafsir Tematik Terhadap UU No.30 Tahun 2004 Tentang Jabatan Notaris, Refika Aditama,Bandung, p. 16.

${ }^{17}$ Karuniawan, Huddhan Ary, "Keabsahan Pemberian Barcode Pada Minuta Akta Dan Salinan Akta Notaris", Jurnal Komunikasi Hukum, Volume 4 Nomor 2 August 2018.

18 Putra, Ferdiansyah, "Perlindungan Hukum Terhadap Para Pihak Yang Dirugikan Atas Penyuluhan Hukum Oleh Notaris", Jurnal Komunikasi Hukum, Volume 4 Nomor 2 August 2018.
} 
contents of the deed are the actions of the parties and not the actions or actions of a notary.

Notaries only formulate the wishes of the parties so that their actions are set forth in the form of an authentic deed or notarial deed. The party who feels aggrieved and who wants to sue the notary must first be able to prove the following:

a. There is suffering loss;

b. There is a causal relationship between the losses suffered and the violation or negligence of the notary;

c. The violation (act) or omission is caused by an error that can be accounted for by the notary concerned.

The conditions as described above also apply to the deed of establishment of a PT which contains a defect of will due to false information from the appearers. In principle, a notary is passive in serving the parties who appear before him.

The notary is only in charge of recording or writing down in the deed what the parties have explained, they have no right to change, reduce or add to what is explained by the parties. The explanation part of the UUJN which states that the authentic deed essentially contains the formal truth in accordance with what the parties have notified the Notary. This was also confirmed through the Jurisprudence of the Supreme Court in the Supreme Court's Decision Number 702 K/Sip/1973 dated September 5, 1973 which stated “...The function of a Notary is to only record/write down what is desired and stated by the parties who appear before the Notary. There is no obligation for the Notary to investigate materially anything (things) put forward by the appearer before the Notary.

\section{Closing}

Procedures for Making a Limited Liability Company (PT) Legal Entity Registration Deed, namely must meet the requirements in the establishment of a PT other than those stipulated in Article 7 paragraph (1) of the Company Law, which must be based on an agreement made by 2 (two) or more people, the form of the Deed of Establishment of a PT must also be in the form of a Notary Deed made in Indonesian, in other words, in this case, the Notary has a role to make the Deed of Establishment of the PT, which functions as probationis causa and solemntasis causa. In Article 8 paragraphs (1) and (2) of the Company Law, it is stated that the Deed of Establishment of the PT contains the Articles of Association and other information such as the identity of the name of the shareholder. The Deed of Establishment of the PT which contains the Articles of Association of the PT as stipulated in Article 8 must contain all the provisions stipulated in Article 15 
paragraph (1) of the Company Law which contains at least the name and domicile of the Company, the purposes and objectives as well as the Company's business activities; The period of establishment of the Company, the amount of authorized capital. Issued and paid-up capital, number of shares, classification of shares if any, including number of shares for each share classification, rights attached to each share, and nominal value of each share, name of position and number of members of the Board of Directors and Board of Commissioners, determination of place and procedures procedures for holding GMS, procedures for appointment, replacement, dismissal of members of the Board of Directors and Board of Commissioners, procedures for using profits and distribution of dividends. The notary is only formally responsible for the documents shown to him, in which the notary has no obligation to materially prove the truth of the documents shown to him. However, the notary must conduct an examination of all documents submitted to him which then also asks the appearer for information to be synchronized with the information contained in the document, in which case there are irregularities related to the documents and information submitted to him, the notary may refuse to continue the stages of making the deed. . Notaries can only be held accountable if the Notary is proven to have violated the provisions of Articles 84 and 85 of the UUJN and the notary code of ethics, which can be held criminally, civilly and administratively responsible.

\section{References}

Journals:

[1] A Chuasanga, Ong Argo Victoria. (2019). Legal Principles Under Criminal Law in Indonesia Dan Thailand, Jurnal Daulat Hukum, Vol 2, No 1 (2019) http://jurnal.unissula.ac.id/index.php/RH/article/view/4218

[2] Deen, Thaufiq., Ong Argo Victoria \& Sumain. (2018). Public Notary Services In Malaysia. JURNAL AKTA: Vol. 5, No. 4, 1017-1026. Retrieved from http://jurnal.unissula.ac.id/index.php/akta/article/view/4135

[3] Karuniawan, Huddhan Ary, "Keabsahan Pemberian Barcode Pada Minuta Akta Dan Salinan Akta Notaris", Jurnal Komunikasi Hukum, Volume 4 Nomor 2 August 2018.

[4] Putra, Ferdiansyah, "Perlindungan Hukum Terhadap Para Pihak Yang Dirugikan Atas Penyuluhan Hukum Oleh Notaris", Jurnal Komunikasi Hukum, Volume 4 Nomor 2 August 2018.

Books:

[5] Sjaifurrachman dan Habib Adjie, 2011, Aspek Pertanggungjawaban Notaris Dalam Pembuatan Akta, Mandar Akta, Bandung

[6] Abdul Ghofur Anshori, 2009, Lembaga Kenotariatan Indonesia, Perspektif Hukum dan Etika, UII Press, Yogyakarta 
[7] Habib Adjie, 2008, Hukum Kenotariatan di Indonesia-Tafsiran Tematik Terhadap UU No. 30 Tahun 2004 Tentang Jabatan Notaris, Bandung, Refika Aditama.

[8] Habib Adjie, 2008, Hukum Notariat di Indonesia : Tafsir Tematik Terhadap UU No.30 Tahun 2004 Tentang Jabatan Notaris, Refika Aditama, Bandung

[9] Kitab Undang-undang Hukum Perdata

[10] M. Yahya harahap, 2016, Hukum Perseroan Terbatas ed.6, Sinar Grafika, Jakarta

[11] Undang-Undang Nomor 40 Tahun 2007 Tentang Perseroan Terbatas

[12] Munir Fuady, 2003, Perseroan Terbatas Paradigma Baru, Citra Aditya Bakti, Bandung

[13] Gunawan Widjaja, 2002, Seri Hukum Bisnis Tanggung Jawab Direksi atas Kepailitan Perseroan, Raja Grafindo Persada, Jakarta

[14] Gunawan Widjaja, 2008, Risiko Hukum sebagai Direksi, Komisaris \& Pemilik PT, Forum Sahabat, Jakarta

[15] Utomo, Hatta Isnaini Wahyu, 2019, Memahami Pelaksanaan Tugas Jabatan Pejabat Pembuat Akta Tanah, Phoenix Publisher, Yogyakarta

[16] Budiono, Herlien, 2013, Kumpulan Tulisan Hukum Perdata di Bidang Kenotariatan, Buku Kedua, Citra Aditya Bakti, Bandung

[17] Adjie, Habib, 2008, Hukum Notariat di Indonesia : Tafsir Tematik Terhadap UU No.30 Tahun 2004 Tentang Jabatan Notaris, Refika Aditama,Bandung 